\title{
A Short Review of Submerged Breakwaters
}

\author{
Ibrahim 'Izzat Na'im 1,*, Ab Razak Mohd Shahrizal ${ }^{1}$, and Mat Desa Safari² \\ ${ }^{1}$ Department of Civil Engineering, Faculty of Engineering, Universiti Putra Malaysia 43400 Serdang Selangor, Malaysia \\ ${ }^{2}$ National Hydraulics Research Institute Malaysia (NAHRIM), 43300 Seri Kembangan Selangor, Malaysia
}

\begin{abstract}
Breakwaters are used around the globe as a mean of protection against beach erosion by reducing the height of incoming waves into smaller transmitted waves. In addition, breakwaters can efficiently be used to preserve tranquillity inside the harbour basin, to decrease the deposition of sediments that can lead to water pollution at the harbour entrances, and to be a sanctuary for marine habitats. The purpose of this study is to discuss the application of the innovative submerged breakwater globally and in Malaysia. In addition, the comparison between submerged and emerged breakwater are briefly explained to understand the distinction between these two structures. The future experiment of the newly developed breakwater in Malaysia known as WABCORE is also included in this paper where the experimental setup and expected results are discussed.
\end{abstract}

\section{Introduction}

Departing from the rubblemound breakwater to hemispherical shape of artificial reefs and from emerged to submerged breakwaters, the evolution of breakwaters has been undergoing a lot of changes. Most of the changes are to suit certain needs or to move in the direction of environmental-friendly methods. Around the world, breakwaters are the preferred choice as they are capable of dissipating wave energy, provide protection to the shore and act as habitat for marine life. As time goes, submerged breakwaters have becoming more popular compared to the conventional breakwaters (emerged breakwater) due to the reason that they are more appeal. However, there are claims that submerged breakwaters are not as capable as its predecessor. Some would say otherwise depends on the design characteristics. In this section, several topics are discussed. The innovation of submerged breakwater and its application in Malaysia and around the world are reviewed. They show the different aspect and characteristic for each structure. Next, the comparison between the submerged breakwater and emerged breakwater are discussed from the previous studies and cases to find the advantages and disadvantages both of the structures.

\section{Submerged versus emerged breakwater}

Generally, there are three types of breakwater relative to position of sea level which are emerged breakwater, lower limit breakwater and submerged breakwater as depicted in Fig. 1 as (A), (B) and (C) respectively [1]. However, only emerged and submerged breakwater are discussed in this study. Emerged breakwater can be defined as a structure that has been built offshore with its crest above the higher sea level (HSL), mean sea level (MSL) and lower sea level (LSL). In contrast, submerged breakwater's crest is usually below all of those three level. The breakwater is constructed to give protection against wave action and sometimes, against currents action [2]. Breakwaters are constructed to minimize wave action in an area behind the structure where wave action is reduced through reflection and dissipation of incoming wave energy [3]. It is suggested that the breakwaters can be classified into two categories which are sloping front face and vertical front face [3]. Sloping front face usually is made up of rubble-mound structure while vertical front face is comprised of sand-filled concrete caissons. 


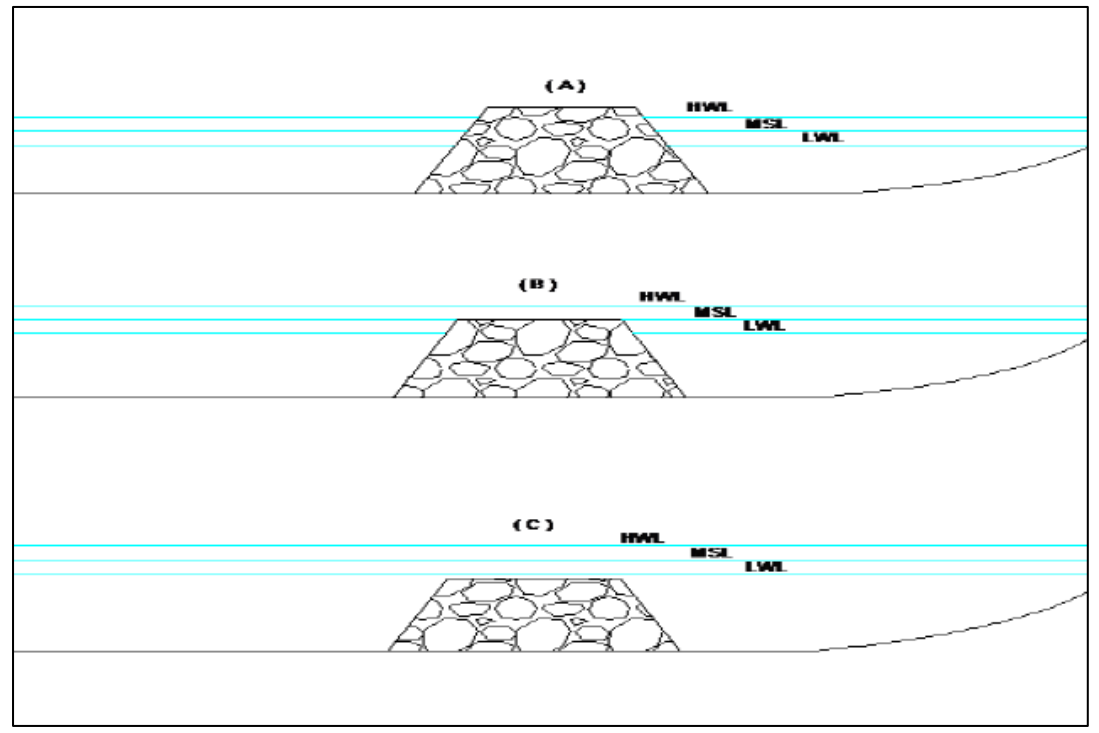

Fig. 1. Type of breakwater relative to sea level; Emerged (A), lower limit (B) and submerged (C) [1]

Since the implementation of the submerged breakwaters as protection from the coastal erosion becoming more popular around the globe, a question arouses whether the submerged structures are capable of protecting the beach. It is inevitable that when certain things or technologies are being innovated, they will be compared to their predecessor in terms of capabilities, qualities and improvement. In this case, the predecessor is referred to emerged breakwaters. It is reported that seven out of ten submerged breakwaters are undergoing erosion at the lee of the structures [4]. On the other hand, shoreline erosion is almost never reported for conventional (emerged) breakwaters. This shows that the capability of the emerged breakwater in controlling beach erosion is better than the submerged breakwaters. Study shows that when the permeable submerged breakwater is applied, higher wave heights were observed in the lee of the structure and smaller salient is formed compared to the emerged offshore permeable breakwater [5]. It is known that waves are the main cause of coastal erosion. The higher the wave energy, the higher the rate of erosion [6]. In salient formation cases, it is claimed that in some cases, the submerged breakwaters form larger salient compared to the emerged breakwaters [4].

There is inconsistency between submerged and emerged breakwaters in dissipating wave energy. The experiment regarding to the submerged and emerged breakwater was conducted as a project at University of Wisconsin-Madison [7]. The results show that the energy reduction of submerged breakwater is $65.11 \%$ while the energy reduction of emerged breakwater is $37.12 \%$. A study on protection of tsunami-induced by offshore breakwaters was performed [8]. In the study, the submerged and emerged breakwaters were tested with several parameters to find the effect of the structures on scour protection. The experimental results showed that emerged breakwater is more effective in reducing tsunami scouring compared to the submerged breakwater. The results from the study indicate that the submerged breakwater only affected the height and the position of the deposition sand bar. In addition, it is stated that the absence of the emerged breakwater results in erosion on the shore face due to the significant portion of scouring [8]. [9] carried out a study on the emerged and submerged semi-circular breakwaters. It concluded that the submerged semi-circular breakwater allows less transmission compared to the emerged semi-circular breakwater which indicates an extra amount of energy is dissipated by perforations in the semi-circular caisson.

A study on the both emerged and submerged breakwaters was performed in Ostia, Italy [10]. The paper also discussed on the cost comparison between two types of the breakwaters. In the study, the beach is divided into four zones namely Zone A, Zone B, Zone C, and Zone D. In 80's, emerged breakwaters are constructed at the zone A which resulting on good protection against erosion. However, the hard structures are not preferred for the bathing purpose and recreational use in the tombolo areas. In addition, the areas are prone to bacterial reproduction which is a danger for the beach users' health. After a few years, the application of soft structures, beach nourishment is used together with submerged rubble mound breakwater in zone B. However due to the high cost, the government decided to implement cheaper type of beach protection which is submerged breakwater in zone $\mathrm{C}$ and zone $\mathrm{D}$. The submerged breakwaters are becoming a favourite in defending the shoreline erosion, build artificial beach to reduce the need of sand supply, retained aesthetic value, and assure water circulation to maintain good water quality for bathing purpose. In terms of cost, the authors claimed that there are no different between emerged breakwaters and submerged breakwaters which is about two million US dollars per kilometres. However, there are several reports made that have different claims on the costs of the structures. Submerged breakwaters have relatively low cost compared to the emerged breakwater although no solid study on actual cases are presented along the claim [11]. There is a claim that the construction cost of submerged breakwater is relatively cheaper compared to the existing emerged breakwater [12]. 


\section{Types of submerged breakwater}

To date, there are various type of breakwaters that have been implemented around the world. Breakwater design is flexible as it can be constructed to suit certain needs. Some breakwaters are constructed to protect the beach from the erosion while some are constructed for the same purpose without having to ruin the aesthetic value of the beach. In some part of the world. Breakwaters are built to act as coral restoration. Some looking for breakwaters with cheaper alternative and eco-friendlier material. In addition, breakwater design is different from each other because the parameters of the waves and the condition of the beach is different from one place to another. That is why it is important for a field study and proper design to ensure the structure performs effectively. In this section, some of the submerged breakwater types around the globe are discussed due to its relationship with future study.

\subsection{Perforated concrete block}

Porous breakwater had been widely used to decrease the impact of the wave force that reached the front part of vertical wall breakwater when [14] had first suggested it [13]. These types of structures could reduce the volume of concrete using and it is environmental friendly because the large pore which could act as the home of marine biota [15] One of the highlighted characteristics of a porous breakwater is that the wave energy will break if it hits the front part of the permeable and porous vertical wall breakwater [13]. In addition to that, the incoming wave will continue to hit the pore which cause the reduction of the wave reflection in front of the breakwater structure. Initially, the design of the porous breakwater is based on caisson type of breakwater whose front wall facing the sea has a hole and the rear part is allowed to be permeable. The wave pressure acting on the porous wall is less than the solid wall, as proposed [16].

Study by [15] is to derive a perforated concrete block which performs effectively in reducing the wave height. In their study, the same length scale with height scale (undistorted models) by using Froude similarity is used. Dimensional number analysis method of dimensionless parameters is practiced to show the correlation between parameters and also used to explain the research result. Dimensional analysis is used to determine the dimensionless parameters. Several methods that's commonly used for dimensional analysis are Basic Echelon Method, Buckingham Method, Rayleight Method, Stepwise Method, and Langhaar Method. For their research, Langhaar method is used [15] because the variable affects are less and the method is also ordered systematically. Based on the Fig. 2, the perforated concrete block has similar dimension which is $72 \mathrm{~cm} \times 72 \mathrm{~cm} \times 50 \mathrm{~cm}$. The only differences between the two models are the number of slot which lead to different width of slot. They claimed that the increase of the slots will resulting on the decreasing of the wave height due to the energy dissipated inside the hollow structure [15]. Perforated concrete block is developed to be one of the breakwater types that is eco-friendly, this is because the slots can act as wave dissipater and it can be the home of marine biota to form their habitat Apart from that, a well placement of the perforated concrete block is needed because the well placement gives the good effect of energy dissipation due to the influence of slot width towards the wave deduction level is insignificant.

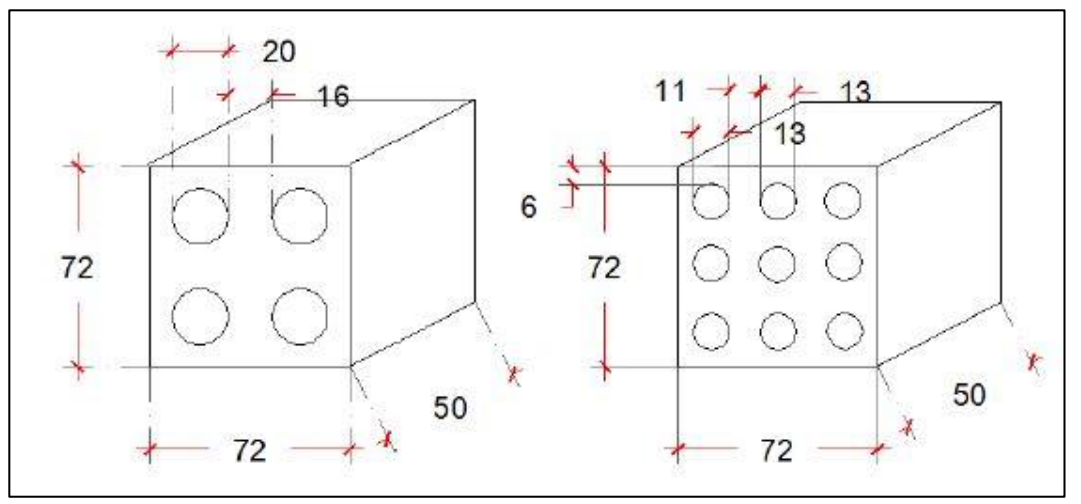

Fig. 2. Type of perforated concrete block breakwaters [15]

\subsection{Geosynthetic tubes}

Geosynthetic tubes have becoming a choice as coastal protection. In India, National Institute of Ocean Technology (NIOT), Chennai has proposed to implement a geosynthetic tube as submerged breakwater at $4 \mathrm{~m}$ depth at Kadalur Periyakuppam (KPK), Tamil Nadu [23]. In the recent years, the east coast of India is repeatedly affected by storms which the major ones being Thane in year 2011, Nilam in 2012, Madi in 2013, and Hud Hud in 2014. KPK is located south of Kalpakkam and consists of three fishing villages between Palar river and north of a creek in that area. Authors said that facilities at the coast of KPK were severely damaged and the accretion in the following calm season is not 
sufficient to restore the beach. The design tensile strength of the stresses developed in circumferential and longitudinal directions during filling of geosynthetic tubes has been found. The design tensile strength of the material is $200 \mathrm{kN} / \mathrm{m}$. Material should have optimum apparent opening size to contain the soil particles as well as to permit the water to drain off at ease. Based on the design, an apparent opening size of $0.25 \mathrm{~mm}$ is provided. In addition, the material of geosnthetic is designed to have a tensile strength of $75 \%$ of actual strength after being exposed to UV radiation for 500 hours. Stability analysis of the breakwater is performed by using various methods available in the literature as there are no standard guidelines available for estimating the wave loading on the geosynthetic tubes. The estimation of the wave loading from available methods is $45 \mathrm{kN}$ per metre length of breakwater. Furthermore, the breakwater is safe against overturning $(\mathrm{FoS}=2.65)$, sliding $(\mathrm{FoS}=18)$ and bearing capacity $(\mathrm{FoS}=5)$. For a $2 \mathrm{~m}$ wave, it was found that the maximum scour depths at the offshore and onshore side are $75 \mathrm{~cm}$ and $8 \mathrm{~cm}$ respectively.

Apart from India, the geosyntehtic tubes area also practiced in Mexico. The beaches of the Northern coast of Yucatan in Mexico have been undergoing perpetual erosion process that has gradually increased in the past 15 years [24]. Changes in the littoral dynamics, mostly because of human activities, have generated a coastline regression rate, estimated at $1 \mathrm{~m}$ per year and more. In addition, the region is affected by all the hurricanes that follow a path through the Gulf of Mexico. Risk of damage due to extraordinary wave conditions is severe. Due to this circumstance, geosynthetics were chose to be the optimal solution for the beach restoration project. Woven polypropylene geotextile tubes were designed to be low-crested submerged structures. Their main purpose was to reduce the incident wave energy on the beach, by regulating the wave-breaking process, to the desired level that maintains the dynamic balance on the shoreline. Once the littoral process was assessed, a tube cross section was designed and geosynthetic materials were designated in terms of their mechanical properties. The mechanical parameters, geometrical parameters and the cross section of the geosynthetics tubes are given in the Fig. 3.

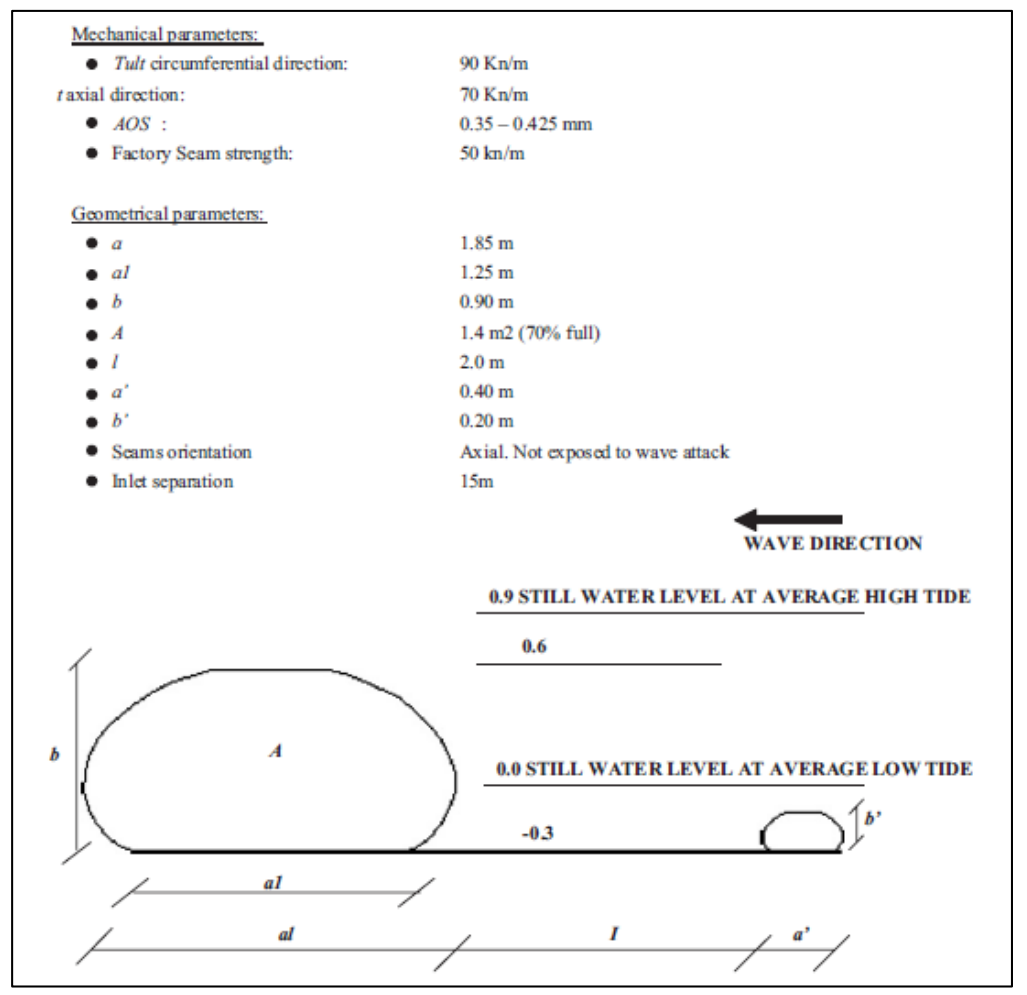

Fig. 3. Mechanical parameters, geometrical parameters and the cross section of the geosynthtic tubes [24]

Up to March 2006, 18 months of monitoring has been performed since the first geotextile tube was installed. The performance of the structures is evaluated based on two perspectives which are marine processes response and geosynthetics materials behaviour. Geotextile tubes have been excellently working as parallel submerged breakwaters. The wav energy is dissipated by the wave breaking due to the presence of tubes. Turbulence-generated shoreward induces sand accumulation without disrupting littoral drift process. Furthermore, there are no changes of natural current patterns seaward of tubes. Beaches reach their equilibrium profile with no significant alteration to alongshore sediment transport [24]. For the behaviour of geosynthetics materials, there is no much to discuss by the authors. They stated that in the case of the Yucatan project, during the littoral process, tubes may be naturally covered by seaweed and marine 
flora, which are desirable since they support additional UV protection. Apart from that, tensile strength for geosynthetics is maintained mainly by slurry-pumping pressure. Most of the tubes were equipped with pumping equipment from inland and offshore sediments banks, with no overstressed geotextiles spotted.

In another part of the world, one of the developed country in Asia, South Korea also using geotextile tubes in the protection of the eastern Korean shore. A study on geotextile tubes was performed in the East Sea [25]. Presently, shore erosion is causing serious damage to shoreline aesthetic views and to public property along the east coast of Korea. The cause of the erosion is due to several aspects such as energy of wave attack, periodic tides, and currents which are originated from the effect of seasonal winds. East Korea Warm Current (EKWC) and North Korea Cold Current (NKCC) are the dominant cause which affect the circulation patterns of upper waters in the Ullung Basin. When the significant wave heights reach up to four meters, the process of shoreline erosion on the east coast of Korea is depicted to be the most severe during winter season. The erosion process remains severe even after early spring season during four months, as the shoreline have become harder and high energy wave due to the current and storm can still strike them [25]. Before the usage of the geotextile tubes, they used semi-interlocking precast concrete segments (tetrapod structure). However, this method needs arrangement for an appropriate foundation to support the super-structure, including a toe protection which will maintain the stability of the structure under design wave forces. In addition, relatively heavy duty equipment is required for breakwater construction and it is noted that construction works and procedure are difficult as compared to construction of similar structures on the shore area. Therefore, the city and province officials deliberated the idea of other alternative solution to find cheaper and environmental sustainable technology and thus, geotextile tube technology was implemented in Young-Jin beach on the east coast of Korea. The properties of the geotextile tube and its filling material are depicted in Figure. 4.

\begin{tabular}{|c|c|c|c|c|c|}
\hline \multicolumn{5}{|l|}{ Table 5} & \\
\hline Physical properties & Test method & Unit & Min. value & & \\
\hline Material, weight & ASTM D-5261 & $\mathrm{Oz} / \mathrm{yd}^{2}$ & PP, 20.0 & Item & Quantity \\
\hline Tensile strength & ASTM D-4632, 4595 & $\mathrm{kN} / \mathrm{m}$ & 175.0 & Specific gravity, $G_{\mathrm{s}}$ & 2.64 \\
\hline Elongation & ASTM D-4632, 4595 & $\%$ & 18.0 & Effective size, $\mathrm{D}_{10}(\mathrm{~mm})$ & 0.50 \\
\hline Tear strength & ASTM D-4533 & $\mathrm{kN} / \mathrm{m}$ & 70.0 & Uniformity coefficient, $C_{\mathrm{u}}$ & 1.90 \\
\hline Seam strength & ASTM D-4884 & $\mathrm{kN} / \mathrm{m}$ & 105.0 & Coefficient of gradation, $C_{\mathrm{c}}$ & 0.84 \\
\hline Equivalent opening size & ASTM D-4751 & US Sieve & $\# 100$ & Max. dry unit weight, $\gamma_{\mathrm{d}(\max )}\left(\mathrm{kN} / \mathrm{m}^{3}\right)$ & 16.38 \\
\hline Permittivity & ASTM D-4491 & s & 0.10 & Optimum moisture content, $w_{\text {opt }}(\%)$ & 14.2 \\
\hline Ultraviolet degradation & ASTM D-4355 & - & $70 \%$ & Interface friction angle(dry) $\left({ }^{\circ}\right)$ & 34.7 \\
\hline (percent strength & & & & Internal friction angle(wet) $\left({ }^{\circ}\right)$ & 32.0 \\
\hline retained@500h) & & & & USCS & SP \\
\hline
\end{tabular}

Fig. 4. Properties of the geotextile tube and its filling material [25]

Prior to the completion of geotextile tube construction, the four twin submerged detached geotextile tubes were installed at various locations throughout the Young-Jin beach area. The size of a single geotextile tube is $50 \mathrm{~m}$ long and $1.8 \mathrm{~m}$ tall. Observation shows that sea weed has colonized the surface of the tube and sand has accumulated on its upper surface. After the installation works were completed, the changes in shoreline and water depth near shore were monitored over a 12 months' period. The results show that the shoreline at BM1 was extended by about $5.3 \mathrm{~m}$ during a three months' period, due to the short-term effectiveness of wave absorption and diminution of sea bed soil migration. However, three months after the event, the shoreline of BM1 was found to be re-eroded by tidal waves. The authors suspected that this problem might be arises from local effects (changed tidal flow direction and velocity) caused by the very geotextile installation itself. Also, the shorelines at BM3 and BM4 were monitored similarly to that at BM1, but the magnitude of re-erosion was found to be insignificant. On the contrast, the shoreline of BM2 was continuously extended by the wave adsorption of tidal waves.

\subsection{Reef balls ${ }^{\mathrm{TM}}$ breakwaters}

Reef balls are hollow hemispherical-shaped artificial units (Fig. 5) designed for improvement in biological growth and coral reef restoration and also acting as coastal protection structure [26]. The reef ball can be allowed to stay in the original area where it was stationed for enhancement of marine growth, or it can be harvested and moved to other places such as natural or artificial aquariums. Reef balls are constructed from concrete with a $\mathrm{pH}$ of about 8.3, near to that of the sea. This allows Reef Balls to blend in the marine environment and reducing potential negative impacts and disturbing the development of the existing ecosystem [27]. 


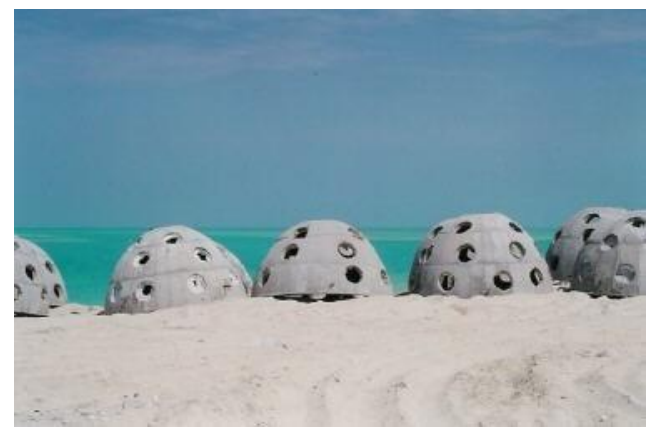

Fig. 5. Example reef balls unit [29]

There are few types of reef balls such as standard, layer cake (Fig 6), lobster cake, stalactites, stalagmite, predator exclusion, net deterrent, seagrass, abalone surface, oyster surface, custom sculptures, eternal reefs, and red mangrove planter styles. With this various type of styles, it also comes with few different anchoring options such as fiberglass rebar anchors, horizontal stabilizer feet, anti-trawling piles, piles support, and extended bottoms [28]. Although the main purpose of reef balls is coral restoration and enhance biological growth, it also can serve as protection and renewal by acting as wave attenuation devises (WADs) which create habitat providing environmental benefits beyond erosion control. There are a lot of example of reef balls submerged breakwaters implementation in the world such as Marriott Beach Resort (Cayman Island), Maiden Island (Antigua), Venice lagoon (Italy), and other places [39].

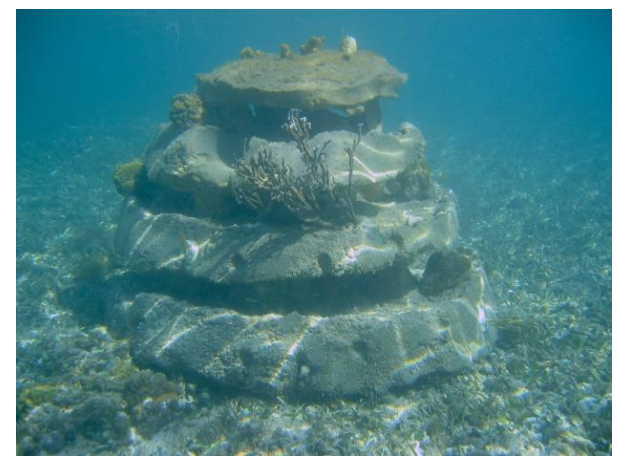

Fig. 6. Layer cake style [29]

The purpose of the construction of Reef Ball breakwater at Marriott Beach Resort was to at produce the shoreline stabilization and enhancing growth of flora and fauna which lead to the improvement of the beach's aesthetic value [30]. The resort located in the southern part of Seven Mile Beach, Cayman Island, was damaged due to significant erosion phenomenon which was caused by alongshore sediment transport, directed from south to north. From April 1994 to November 2002, the beach retreated up to the foot of seawall near the hotel structure and approximately $30.5 \mathrm{~m}$ erosion was registered from 1997 to 2002 [29] [30]. In year 2002, a segmented submerged breakwater made of five rows of Ultra Ball units was constructed shoreward a natural reef (Fig. 7), about $49 \mathrm{~m}$ far from the beach. The two Reef Ball breakwaters were, respectively, $43.9 \mathrm{~m}$ and $29.26 \mathrm{~m}$ long, $7.62 \mathrm{~m}$ and $9.14 \mathrm{~m}$ wide, with a submergence of 0.10 and $0.55 \mathrm{~m}$. Five fiberglass rebar was anchored to each module to prevent sliding, driven through the lateral holes of the module to reach the rocky bottom. In addition, various types of corals were implanted on Reef Ball surfaces to advertise the ecotourism and encourage recreational activities such as snorkelling and diving. 


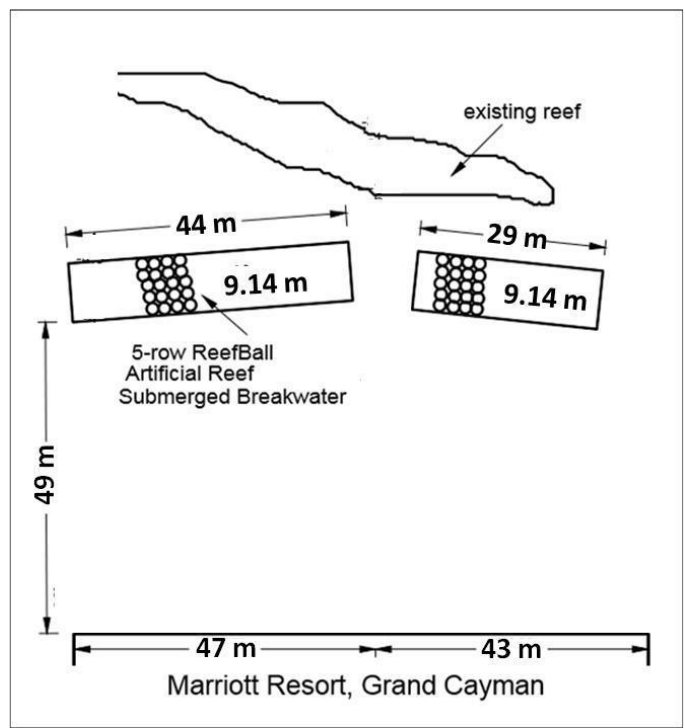

Fig. 7. Graphic representation of the RB breakwater at Marriot Beach Resort [29] [30].

In order to investigate the response of the beach, several surveys were conducted after the finishing of the project. An initial average increment of the shore line of $14.5 \mathrm{~m}$ was recorded from November 2002 to February 2003 [30]. Shortly after the hurricane season and the tropical storms in 2003, the beach was observed to reach a width of about 5.8 $\mathrm{m}$, while adjacent beaches were completely retreated [30]. After Charley, Ivan and Emily Hurricanes attacks between 2004 and 2005, the state of the units was verified, resulting to be stable and retained condition [31]. In order to improve the protection of the beach from SW waves, the existing breakwaters that were made of 200 modules, was top-upped with another 32 additional units in November 2005. In addition, $15 \mathrm{~m}^{3} / \mathrm{m}$ of beach nourishment were approximately done along $3 \mathrm{~km}$ in the southern Seven Mile Beach area, including the Marriott Beach [32]. Thorough monitoring and observation of the beach profile 2008 was performed by [33] between 2002 and 2008. Results shows that overall increment of the beach from $0-9.14 \mathrm{~m}$ to $7.62-21.3 \mathrm{~m}$ can be noticed. The first biological monitoring was conducted in February 2003 which is three months after the finishing of the project and a significant growth of marine species was found. Fig. 8 shows the restoration of the Marriot Beach.
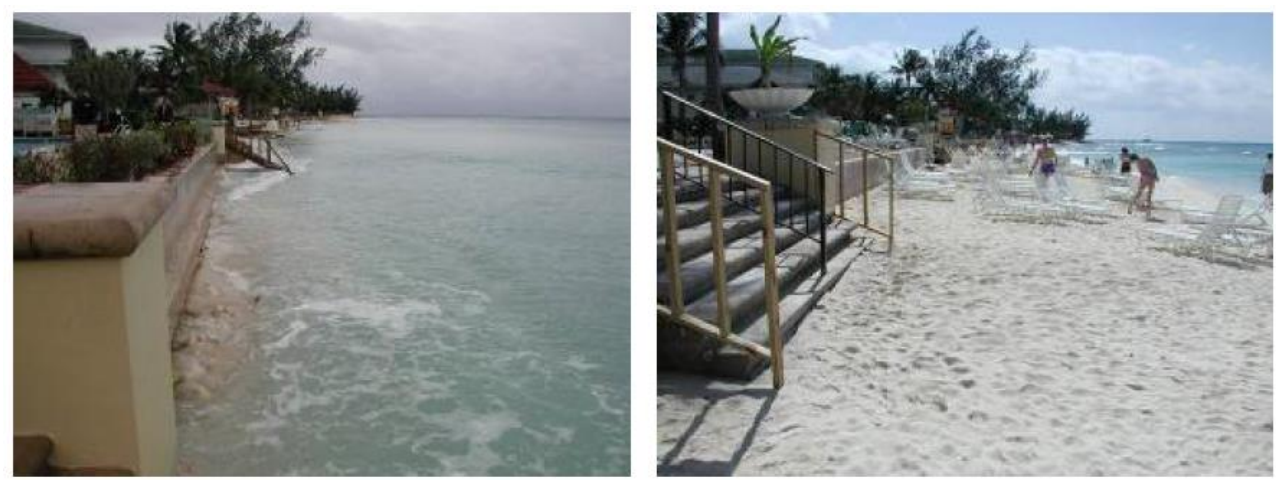

Fig. 8. Marriot Beach before (left) and after (right) Reef Balls breakwater installation [34]

Study by [35] was to develop a model for wave transmission past a submerged breakwater constructed of multiple hemispherical shape artificial reef (HSAR) units and to find the optimum configuration of the reef that will reduce the incident wave energy. The transmission coefficient, $\mathrm{K}_{\mathrm{T}}$, will be expressed as a function of depth submergence, wave height, wave period, reef crest width and reef configuration to observe and identify if any relationships or trends were present [35]. There were 5 reef configurations tested for various wave conditions and water depths to determine their influence on wave transmission as seen in Fig. 9.

Generally, there were two main groups of breakwater configurations to be tested which is baseless HSAR's (Test 2 and Test 3) and HSAR's unit with base attached to the reefs (Test 4, 5 and 7). The base for second group was 
constructed using a $1.0 \mathrm{~m}$ wide base of $4.0 \mathrm{~mm}\left(\mathrm{D}_{50}\right)$ core covered with $36.6 \mathrm{~mm} \mathrm{D}_{50}$ armour stone. The slope of the base is $1: 2$ and has a total height of $22 \mathrm{~cm}$. The rock armour material for the base was chosen based on availability in the laboratory and hydraulic stability was not taken into account. However, there was no serious damage to the armour during the test due to the units being placed relatively far below the water level [35]. Test 6 is to test the conventional submerged breakwater.

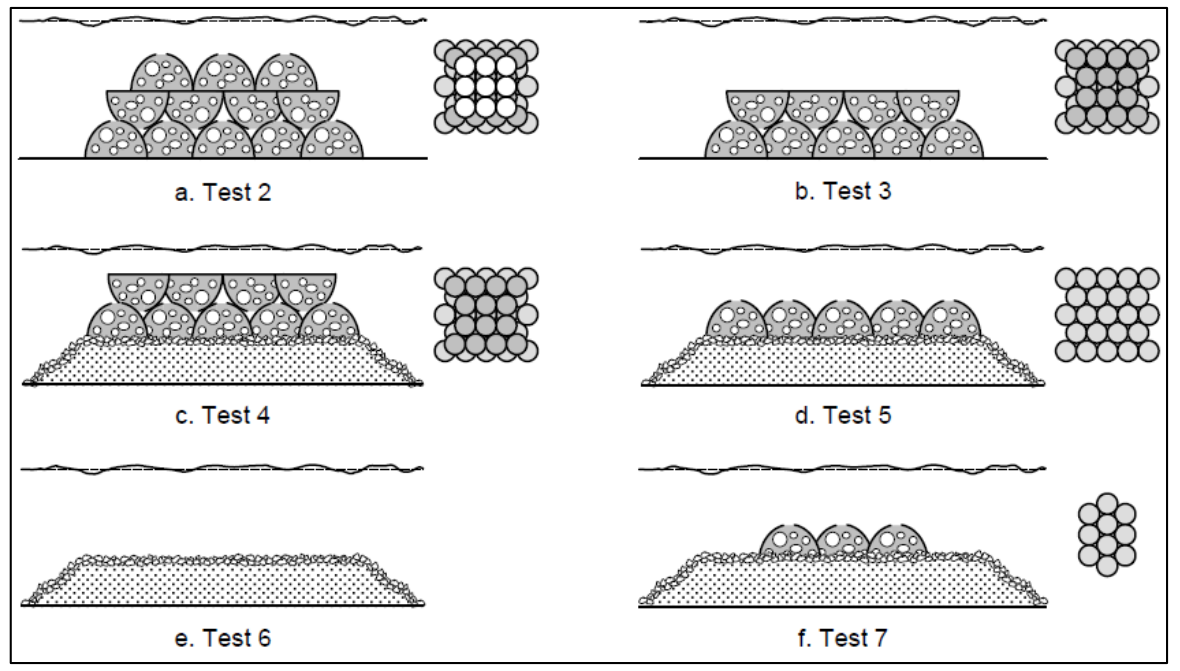

Fig. 9. Configuration of HSAR's unit [35]

Results from the study shows that the incident waves with a high wave steepness in low water depth had the lowest values of $\mathrm{K}_{\mathrm{T}}$ while on the other hand, those at higher depth and lower wave steepness had the highest value of $\mathrm{K}_{\mathrm{T}}$. For low depth of submergence, the influence of breakwater width is noted but this effect becomes insignificant as the water depth increases. This is because the incident waves do not really in contact with the reef surface resulting in ineffective wave attenuation. Test 5 had the lowest transmission at all depths of submergence $(\mathrm{h} / \mathrm{d})$ except for when $\mathrm{h} / \mathrm{d}=1$ where Test 3 results displayed the lowest transmission. Generally, the performance of Test 5, 3 and 4 topped the other Tests' performance but the top layer of Reef Balls in Test 3 and Test 4 were unstable when waves attacked compared to those in Test 5. The highest transmission occurred in Test No. 2. Furthermore, the difference between wave transmission obtained from regular and irregular wave tests was insignificant [35]. Authors also conclude that HSAR was able to dissipate approximately $60 \%$ of incoming wave energy in average.

\section{Practical application of submerged breakwater in Malaysia}

In this section, several innovations of submerged breakwater in Malaysia are discussed. This section also covers the description of the structures of the submerged breakwater, the approach adopted, and its efficiency.

\subsection{Artificial Mangrove Root System (ArMS) submerged breakwater}

The idea of artificial mangrove root system as beach protection is due to the negative public reaction against hard rock structures such as breakwaters, groyne and seawall. Because of that, a "soft-methods" such as beach nourishment, submerged breakwaters, artificial reefs, floating breakwaters, etc. are widely used [36]. ArMS geometrics were designed by taking the complicated mangrove root system and simplifying them to be a porous submerge structure. The author stated that this innovation is based on the thought of protecting the coastal area for wetland rehabilitation, improving marine life, and prevent destruction on the shore line. [37] proposed that the structures can acts as protection to the mangrove seedlings by allowing sedimentation build-up in soft muddy coast due to its performance in dissipating wave energy. Fig. 10 shows the geometry of the ArMS.

The study conducted by [36] was to find the hydraulics performance based on the numerical and experimental models. The numerical models are constructed by using Flow-3D software while the experimental models are conducted in the wave flume available in the Hydraulic Laboratory of the Coastal and Offshore Engineering Institute at Universiti Teknologi Malaysia. 


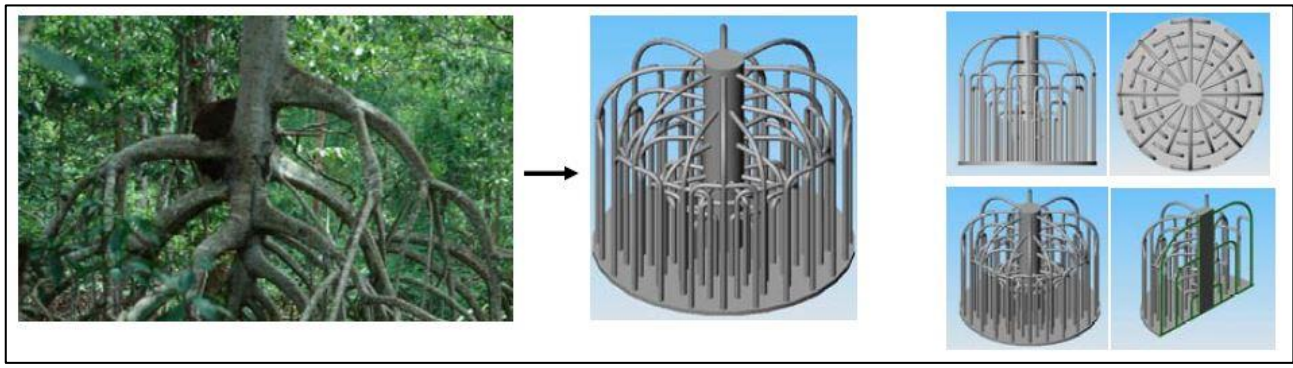

Fig. 10. The geometric model of the mangrove root system submerged breakwater [36]

\subsection{Geotextile tubes}

Geotextile tubes can be used for several of hydraulic and coastal applications where mass gravity barrier-type structures are required such as revetment, offshore dykes (breakwaters) and groynes [38]. For detached breakwaters, geotextile tubes are used as a protection from the erosion. The filled tube is placed at the offshore to dissipate wave forces before they can reach and break at the shoreline. These tubes may either be submerged or emerged [24]. Usually, the material of the geotextile tubes is made of polypropylene woven geotextiles with ultimate tensile strengths ranging from 100 $\mathrm{kN} / \mathrm{m}$ to $200 \mathrm{kN} / \mathrm{m}$ in both warp and weft directions [38]. The authors also stated that during the manufacturing of the geotextile yarns, it was treated for high ultra-violet (UV) resistance in addition of UV stabilizers. The fabric also capable in withstanding weathering and abrasion which is critical aspects in coastal and marine applications. In Malaysia, the application of the geotextile tubes is spotted in the east coast of Malaysia. The pilot project a Teluk Kalong, Kemaman, Terengganu had been studied by [38] The beach along the coast of Teluk Kalong is mainly granular sandy materials. Approximately, $500 \mathrm{~m}$ of the shoreline is expose to serious erosion which caused the damage to the existing seawall. The beach also is not suitable for recreational use due to the narrow and steep shoreline. In 2006, Public Works Department (Jabatan Kerja Raya, JKR) decided to use geotextile tube as detached breakwaters. The tubes are installed with a length of $500 \mathrm{~m}$ along the beach front with certain design requirement such as the tubes are to be placed $150 \mathrm{~m}$ from the shoreline and must be submerged with freeboard of one-meter height. The purposes of the tubes are to protect and decrease the shoreline erosion and to speed up the deposition of the sediments on the shoreline to improve the beach front. After the completion of the installation works, a visual inspection of the project was carried out following the monsoon seasons in 2006, 2007 and 2008. It shows that the condition of the beach is improved with accumulation of sediments on the foreshore which resulting in the widening of the beach. Post-construction bathymetry survey also shows that the sand had accumulated more than $1.8 \mathrm{~m}$ thickness and total volume of $87,310 \mathrm{~m}^{3}$ approximately.

The next case study was situated at Pantai Batu Buruk, Terengganu. The sandy beach in the coast of Terengganu is a recreational place for locals and tourists both. However, the repeated erosion had cause the beach profile rather steep especially during monsoon season. The project consists of protection measures along $5 \mathrm{~km}$ of the beach which required to enhance the quality of the beach front. The geotextile tubes are required to be installed as offshore submerged breakwaters parallel to the shoreline to stop erosion. The design concept is almost similar to the project at Teluk Kalong. The designed requirements that were adopted in this project are that the $5 \mathrm{~km}$ shoreline shall be protected, the tubes shall be placed around $100-150 \mathrm{~m}$ offshore, the estimated water depth during low tide shall be $3 \mathrm{~m}$ and the tubes must be totally submerged with $1 \mathrm{~m}$ freeboard during low tide. This project started on July 2008 and ended around August 2009. During the installation works, the tubes were impacted with monsoon storms between November 2008 and January 2009. After the monsoon season ended, hydrography and topographic survey was carried out in February and March of 2009 to investigate any changes on the beach due to the monsoon storms. Results show that the sections where the geotextiles tubes have been installed does not experienced further erosion. In addition, the deposition of the sand in the steep area was noted and the gradient of the shore also become gentler.

\subsection{Wave breaker coral restoration (WABCORE)}

Wave Breaker Coral Restoration (WABCORE) is a composite system unit developed by National Hydraulics Research Institute Malaysia (NAHRIM). Pre-fabricated concrete structures (Fig. 11) are stacked together to form a simple trapezoidal design which then called as one unit [39]. The WABCORE are arranged in manner of bottom up with wide bottom and narrow hat of 4, 3, 2 and 1 units respectively from the bottom, second and third middle layers followed by the top hat and in narrow crested shape. The mass weight of the prototype is $371.38 \mathrm{~kg}$ with the density of $2400 \mathrm{~kg} / \mathrm{m}^{3}$. The first prototype model was successfully constructed at Pulau Tioman, Pahang and Pulau Tinggi, Johor [39]. 


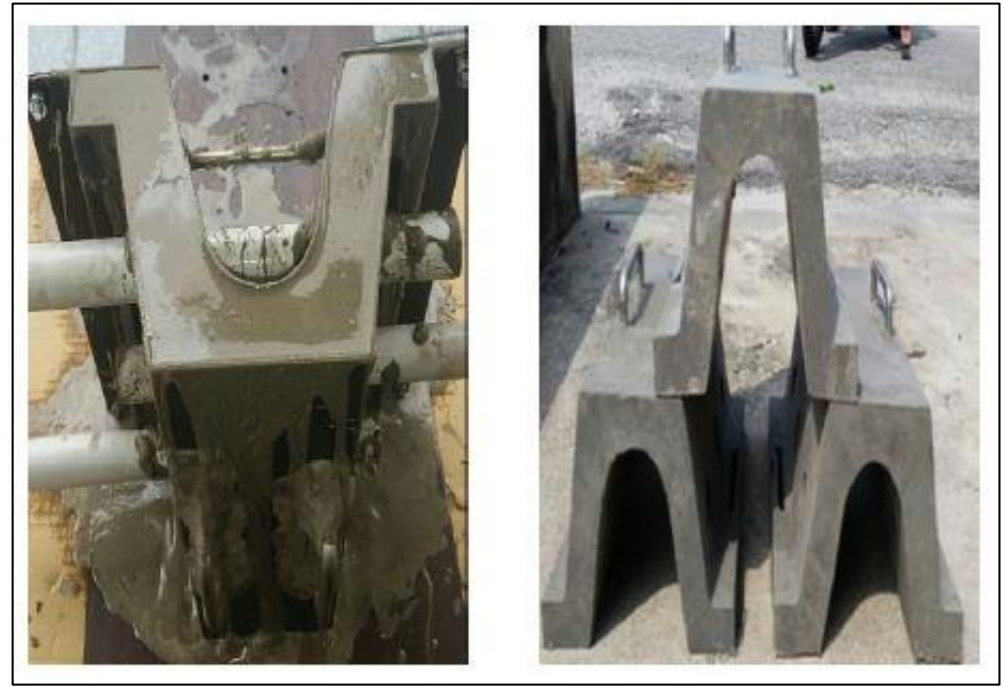

Fig. 11. Progress of construction concrete WABCORE [39]

WABCORE shows an amazing performance for wave transmission when subjected to different sea state condition such as water depths (m), wave periods (s), incident wave height $(\mathrm{m})$ and wave length $(\mathrm{m})$, indicated high wave suppression and capability of WABCORE that promotes wave breaking and structural friction to wave motion. Results are divided into three main parameters which are the effect of relative water depth, incident wave height and relative wave period on the transmission coefficient. The authors found out that the smallest transmission coefficient is lowest when the water depth is the smallest. The value increased as the water depth became larger. For the effect of incident wave height, it was concluded that the smallest water depth and small amplitude of significant wave height, the value of wave transmission coefficient is high. On the other hand, when the smallest value of water depth with bigger wave height, the value of wave transmission coefficient is reduced which shows that incident wave height plays a role in wave dissipation. The third result is about the effect of relative wave period on transmission coefficient. High wave period which resulted into longer wavelength leads to smaller transmission coefficient due to potential of wave passing over the structure. Transmission coefficient become smaller when the value of $\mathrm{H}_{\mathrm{is}} / \mathrm{L}$ at 0.0889 which shows that the wave period is short. Transmission coefficient increased when the $\mathrm{h} / \mathrm{d}$ at 0.5 and 0.4 . The effect of wave period become major factor when water depth is at structural crest level. Physical sea state condition such as water depth and incident wave height shows correlation to the performance of WABCORE. For coral restoration, observation of deployed WABCORE at site recorded coral growth increased rapidly from $8.66 \%$ to $29.75 \%$ from the whole surface of WABCORE in three years.

\section{Preliminary laboratory investigation of submerged breakwater}

There are a lot of studies in regard to investigation of submerged breakwater. Ranging from the investigation of the various kind parameters, type of submerged breakwater, nature of the study and so much more. Although there are differences in conducting the experiment, the purpose is the same, to find whether the structures are able to act as beach protection measures. In this section, several laboratories studies are discussed to study the nature of the study for further understanding.

\subsection{Model setup}

[40] had performed an experiment to investigate the performance characteristic of the submerged breakwaters of various type and shapes which include the permeable and impermeable aspects. The experiments were conducted in the laboratory by using $(25 \mathrm{~m} \times 0.9 \mathrm{~m} \times 0.9 \mathrm{~m})$ with an addition of plunger type regular wave generator. Parallel - wire resistance probe is used to measure the water surface time histories in conjunction with a Kempf and Remmers three channel strip chart recorder. Six types of submerged breakwaters were investigated as such follows:

1) Horizontal fixed plate type

2) Thin vertical wall type (Impermeable)

3) Triangular type (Impermeable)

4) Rectangular type (Permeable and Impermeable)

5) Trapezoidal type (Sea face sloping and beach face sloping; Permeable and Impermeable)

6) Trapezoidal type (Sea face sloping and beach face vertical; Impermeable) 
The details of the breakwater models are depicted in Fig. 12. For impermeable breakwater models, the materials that being used were mild steel and aluminum plates of $6 \mathrm{~mm}$ thickness while permeable breakwaters were constructed with crushed stone aggregates, and the required cross-sections mere maintained by confining the aggregates in mire mesh cages.

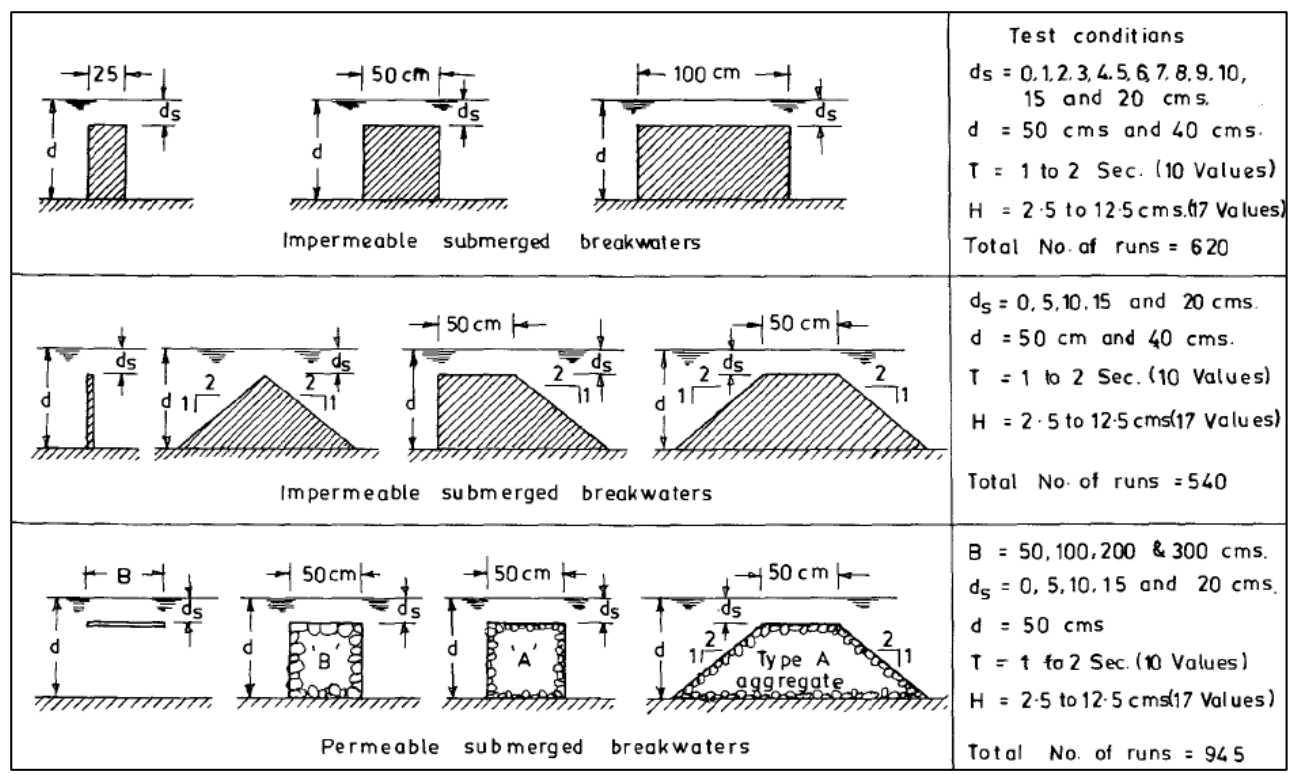

Fig. 12. Submerged breakwaters investigated: test conditions and dimensions [40]

The water depth, d was left constant at $50 \mathrm{~cm}$. The depth of crest submergence, ds, of the breakwater was varied to obtain certain value by altering the crest level of the breakwater while the water depth is maintained. Experiments were conducted covering a wide range of experimental conditions consistent with the available facility. The relative water depth, $\mathrm{d} / \mathrm{L}$ was varied from 0.123 to 0.33 , the incident wave steepness, $\mathrm{H}_{\mathrm{i}} / \mathrm{L}$ was varied from 0.007 to 0.083 , while the relative depth of crest submergence $d_{s} / d$ was varied from 0.0 to 0.4 .

Another study performed by [41] intended to assess the performance of submerged rubblemound breakwaters under a wide range of design conditions in two dimensional (2D) and three-dimensional (3D) settings. Authors claimed that the previous investigations on the performance of submerged rubblemound breakwaters is not sufficient where only a few design equations available to the design engineer. Those available are based on a limited range of input design variables and as a result are insufficient in some cases. Most of the physical tests were 2D in nature and were experimented in a one-meter wave flume at Queen's University Coastal Engineering Research Laboratory (QUCERL), Kingston, Canada. These test results provided the data for development of the proposed design equations. Subsequent 3D testing was carried out in the wave basin at QUCERL using a smaller set of test variables. The results of these tests were used in the evaluation of alternative design equations.

The experimental setup for the $2 \mathrm{D}$ tests is shown in Fig. 13. The wave flume is $(47.0 \mathrm{~m} \times 1.2 \mathrm{~m} \times 1.0 \mathrm{~m})$ is equipped with a flapper type wave generator. A plywood beach and platform was constructed in the flume beneath the breakwater models. The beach allows testing of the submerged breakwaters in relatively large incident waves. The submerged breakwater cross section consisted of a core of relatively course core material $\left(D_{50 c}=0.017 \mathrm{~m}\right)$ and two layers of primary armour $\left(D_{50 a}=0.059 \mathrm{~m}\right)$. A second armour size $\left(D_{50 a}=0.037 \mathrm{~m}\right)$ was used in some tests. The purpose of determination of armour is to ensure the breakwater remained stable during experimenting. The stone size needed for the most severe testing condition was determined using the stability equation from [42]. The stone size recommended for the "total slope" section was applied for the entire breakwater. 


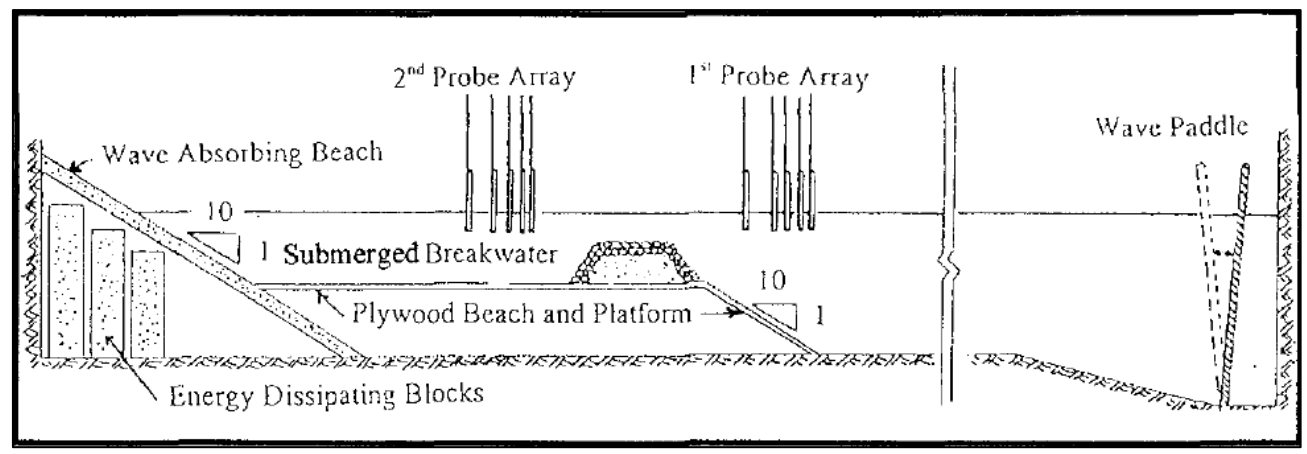

Fig. 13. 2D Testing Configuration [41]

Two wave probe arrays placed in front and rear of the breakwater to measure the incident and transmitted waves respectively. The probes were capacitive type water level gauges, sampling the water surface at $20 \mathrm{~Hz}$. Reflection from the back wall of the wave flume was reduced using a 1:10 beach of rubberized hair and numbers of porous matrix of concrete blocks was placed behind it. There were approximately 800 tests performed with irregular waves. Several tests were also performed with regular waves in order to confirm the presence of physical phenomenon observed by previous authors. The experiments included 13 submerged breakwater different geometries tested under 5 different water levels with a number of incident wave characteristics. Jonswap with $\mathrm{a}=0.0081$ and $\mathrm{y}=3.3$ were used for all irregular wave spectra cases. The signals were generated using the National Research Council of Canada's (NRC), GEDAP wave generation and analysis package. Due to the limitations of flume's physical characteristics and the mechanical response of the paddle to the input signal, the generated wave spectral characteristics may vary from the initial target characteristics by $5 \%$ to $10 \%$. The irregular wave characteristics tested is summarised and provided in Table 1 .

Table 1. Irregular Wave Characteristics in 2D Tests [41]

\begin{tabular}{|c|c|c|c|c|c|c|c|c|c|c|c|}
\hline Wave Set & w01 & W02 & w03 & w04 & W05 & W06 & w07 & W08 & w09 & W10 & W11 \\
\hline$H$ mo $(\mathrm{m})^{*}$ & 0.05 & 0.05 & 0.05 & 0.10 & 0.10 & 0.10 & 0.15 & 0.15 & 0.15 & 0.20 & 0.20 \\
\hline $\operatorname{Tp}(\mathrm{s})^{*}$ & 1.2 & 1.5 & 2.0 & 1.2 & 1.5 & 2.0 & 1.2 & 1.5 & 2.0 & 1.5 & 2.0 \\
\hline
\end{tabular}

* Note: Wave characteristics are target values - those measured in flume may vary to some degree.

Experimental setup for 3D experiments was conducted in the wave basin at QUCERL. The basin $(30 \mathrm{~m} \times 25 \mathrm{~m} x$ $1.2 \mathrm{~m}$ ) is equipped with a piston-type wave paddle $10.5 \mathrm{~m}$ long. All dimensions for the $3 \mathrm{D}$ tests were scaled at 0.63 times those of the 2D tests and the submerged breakwater structure was constructed on the floor of the basin instead on the platform. A concrete beach was constructed at the lee of the breakwater and covered with sand to reduce the reflection and provide a qualitative assessment of beach development. A subset of testing parameters was used in the $3 \mathrm{D}$ tests, with 3 breakwater geometries and 3 water depths, all tested at incident angles of $90^{\circ}$ and $60^{\circ}$. The general experimental setup is shown in Fig. 14 below. 


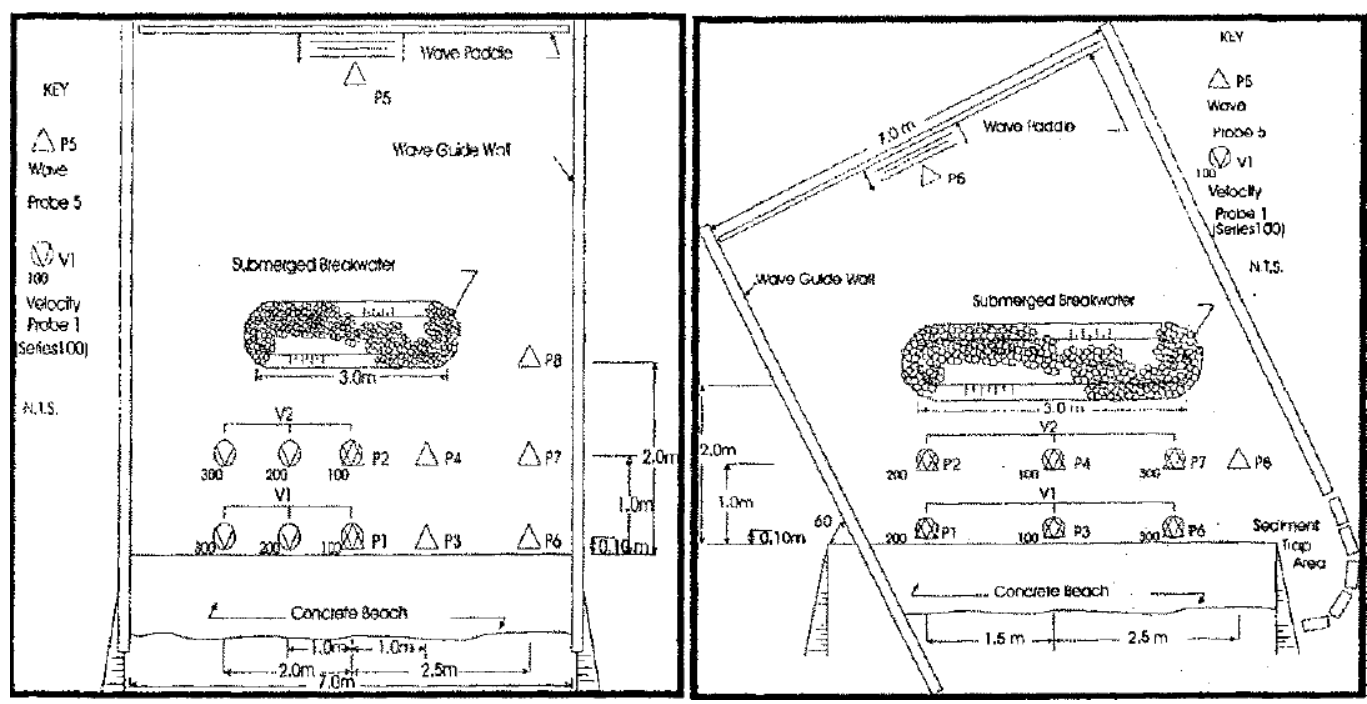

Fig. 14. Testing at $90^{\circ}$ (left) and $60^{\circ}$ (right) [41]

The submerged breakwaters used in the $3 \mathrm{D}$ tests were constructed using a relatively fine core material $\left(D_{50 c}=0.004\right.$ $\mathrm{m})$ and the smallest armour tested in the flume $\mathrm{D}_{50 \mathrm{a}}=0.037 \mathrm{~m}$ ). The wave signals were generated from Jonswap spectra. Since the breakwater for the 3D tests was not placed on an elevated platform, it is impossible to generate waves as large as those used in the 2D tests. A summary of the irregular wave characteristics used in the 3D tests is provided in Table 2 .

Table 2. Irregular Wave Characteristics in 3D Tests [41]

\begin{tabular}{|c|c|c|c|c|c|c|c|c|c|c|c|}
\hline Wave Set & W01 & W02 & W03 & W04 & W05 & W06 & W07 & W08 & W09 & W10 & W11 \\
\hline Hmo $(\mathrm{m})^{*}$ & 0.032 & 0.032 & 0.032 & 0.032 & 0.063 & 0.063 & 0.063 & 0.063 & 0.095 & 0.095 & 0.095 \\
\hline $\mathrm{Tp}(\mathrm{s})^{*}$ & 0.95 & 1.19 & 1.59 & 1.98 & 0.95 & 1.19 & 1.59 & 1.98 & 0.95 & 1.19 & 1.59 \\
\hline
\end{tabular}

* Note: Wave eharacteristics are approximate - those measured in basin may vary to some degree.

\subsection{Performances of submerged breakwaters}

The result obtained from [40] study divided into several section which are:

- Influence of incident wave steepness, $\mathrm{H}_{\mathrm{i}} / \mathrm{L}$ on $\mathrm{K}_{\mathrm{T}}$; Based on [40], the incident wave steepness has major effect on the wave breaking. Waves that near the critical steepness may be induced to break by the submerged breakwater and also likely to be dissipated compared to the flatter waves in terms of energy losses.

- Influence of relative water depth, $\mathrm{d} / \mathrm{L}$ on $\mathrm{K}_{\mathrm{T}}$; The results from the experiments shows that the relative water depth does not have significant influence on $K_{T}$. In smaller range of $d_{s} / d$. the influence of relative depth did not have any influence but on the other hand, the larger range of $d_{s} / d$, bigger value of $d / L$ correspond to relatively deeper water waves, wherein more energy is concentrated near the surface.

- Influence of relative crest width, $\mathrm{B} / \mathrm{L}$, and relative depth of crest submergence, $\mathrm{d}_{\mathrm{s}} / \mathrm{d}$, on $\mathrm{K}_{\mathrm{T}}$; In impermeable submerged breakwaters case, the energy transmission to the shoreward side needs to occurs only above the crest of the breakwaters. Naturally, the amount of energy transmitted across will be greater, if the depth of crest submergence is more. So by any logic, it can be concluded that the relative depth of crest submergence, $d_{s} / d$ is likely to be the most important parameter affecting the performance characteristics of the submerged break waters. Generally, this conclusion can be applied to the permeable breakwaters also, since the energy transmitted through the structure is possibly to be a small percentage of the energy transmitted over the crest. The relative crest width, B/L affects the wave transformation over the breakwater. In the situation where the breakwaters with very small crest widths, it was observed that the incident wave steepens and reaches a condition of near break. But just before the wave can break, it enters the relatively deeper waters in the lee of the breakwater, which then put a stop to it. In the case of breakwaters with sufficient crest width, the wave breaks resulting in a greater dissipation of energy and consequently lesser transmission. In addition, there is insignificant influence of the increasing of crest width where the minimum condition to trigger wave breaking is achieved.

- Influence of shape and slope; It can be concluded that for the different shapes of the breakwaters tested in the experiments, the transmission characteristics were not dependable on the shape. Breakwaters with vertical faces 
on the sea side induce large reflections, creating partial standing waves. These lead to scour and consequent undermining at the base of the breakwaters. Furthermore, large reflections result in greater wave forces acting on the structure due to the formation of the standing wave. These considerations necessarily made the rectangular type of submerged breakwaters was not suitable for practical use. Submerged breakwaters with sloping faces towards the sea have the possible advantage that they allow the flexibility of the sediment movement on its face compared to a vertical face. On the other hand, the sloping faces towards the beach can reduce the efficiency of sediment trapping. Hence the ideal one appears to be a breakwater with sea face sloping and beach face vertical.

- Influence of porosity; In general, authors conclude that the effect of the permeable breakwaters can be very similar to the effect of the impermeable breakwaters. However, the findings contradict with the study by [43] which they found that the behaviour between permeable and impermeable breakwaters were different. It should be noted that the permeable breakwaters used in [43] study were nested tube type whereas study from [40] used crushed stones.

The authors [40] found that the relative depth of crest submergence $d_{s} / d$ and the relative crest width, B/L to be the most significant parameters on the wave transmission coefficient. The performance characteristics for each of the type of breakwater tested can be represented as $\mathrm{K}_{T} \mathrm{Vs} B / \mathrm{L}$ plots with $\mathrm{d}_{\mathrm{s}} / \mathrm{d}$ as the third parameter. The results of the study show that submerged breakwaters can be used as wave attenuator and can be placed where only partial protection from waves is needed. The significant parameters that influence the performance of the submerged breakwaters are the crest width and the depth of crest submergence. In addition, permeability is insignificant, especially for large depths of crest submergence. The shape of the breakwater has significant influence on the reflection characteristics only. The ideal shape appears to be one with the sea face sloping and the beach face vertical. The transmitted wave has the same period as the incident wave, but for cases with the crest of the breakwater near the still water level, higher harmonics are generated. The performance characteristics of the submerged breakwaters can be represented in the form of design charts with the relative crest width and the relative depth of crest submergence as the significant parameters. These curves show remarkable similarity for the different types studied.

For [41] study, the authors stated that the observations made during experiments were generally consistent with observations gained from previous investigations. The major process affecting $\mathrm{K}_{\mathrm{T}}$ was known to be the wave breaking. Inspection of the general trends obtained from the $2 \mathrm{D}$ test data indicate that $\mathrm{K}_{\mathrm{T}}$ is most affected by the parameters such as the depth of submergence $d_{s}$, the incident wave height $H_{i}$, and the crest width $\mathrm{B}$. in addition, $\mathrm{K}_{\mathrm{T}}$ is also influenced by the period of the incident wave $\left(T_{p}\right)$, the breakwater armour dimensions $\left(D_{50 a}\right)$ and the breakwater slopes $(\theta)$ at lesser degree compared to the previous parameters. From the trends that has been plotted in the authors' study, it is found that $\mathrm{K}_{\mathrm{T}}$ increases with increased $\mathrm{d}_{\mathrm{s}}$, increased $\mathrm{H}_{\mathrm{i}}$, and increased $\mathrm{B}$. It is also shown that a small rise in $\mathrm{K}_{\mathrm{T}}$ is observed with increasing $T_{p}$, increasing $D_{50 a}$ and steeper slopes (increasing Tan $\theta$ ).

For $3 \mathrm{D}$ tests, data showed similar trends in general but the scatter in the data was found. The transmission coefficients were higher in the 3D tests due to the attribution of number of factors such as diffraction of wave energy into the lee of the breakwater and reflection of wave energy from the testing apparatus. The results show that the relative submergence depth is the most significant factor under low submergence conditions while crest width is significant under higher submergence conditions. The predicted values of the transmission coefficient for the $2 \mathrm{D}$ test variables were constructed using van der Meer's Equation for submerged and low crested breakwaters and Ahren's Equation for reef breakwaters. The results show that these equations are unsuitable to represent transmission for models tested in authors' study, especially when the crest width is large. The inability of the previous existing design equations to predict suitable transmission coefficients for the tested conditions shows that it is required for an improved design equation [41].

\subsection{Concluding remarks from the experimental results}

From both of the preliminary studies, it can be concluded that both of the studies shows that the important parameters in wave transmission over submerged breakwater is the relative depth of crest submergence $d_{s} / d$ and the relative crest width, B/L to be the most significant. Study by [40] also investigate other parameters such as shape and slope of the breakwater, porosity and relative water depth and found out that these parameters is at lesser degree compared to previous two parameters. [41] improved the study on submerged breakwater by experimenting with 3D tests and found out that relative submergence depth is the most significant factor under low submergence conditions while crest width is significant under higher submergence conditions. In addition, [41] improved the existing equation due to the inability of the data from previous study is not applicable to current study in certain condition.

\section{Future Exploration of WABCORE}

WABCORE have been implemented in certain parts of Malaysia and its capabilities as submerged breakwater and coral restoration were studied as previously discsussed. It shows that WABCORE is effective in dissipating wave energy. Coral restoration study has been performed by [44] on WABCORE in Panuba Bay, Tioman Island, Malaysia. The objective of the study is to determine the colonization of marine epibiota on WABCORE. The WABCORE that were deployed in the Panuba Bay is considered the first prototype. Recently, NAHRIM has developed new prototype for the 
WABCORE. The main feature of the new model is lightweight and cheaper than the previous model. The previous structure's density is at $2600 \mathrm{~kg} / \mathrm{m}^{3}$ while for the new model, it is intended to preserve the density at $1600 \mathrm{~kg} / \mathrm{m}^{3}$. This can be done by substituting part of the aggregate with rubber crumb. This is to reduce the weight and reuse the waste material as part of environmental-friendly purpose. Other than that, the interlocking system of the WABCORE is improved by creating a lock system such in LEGO ${ }^{B}$ blocks. This is because the previous WABCORE collapsed due to the anchoring of boats and deployment of fishing net on the structure [44]. The new study on the new WABCORE is intended to find the wave transmission coefficient on the submerged structure. Other than that, the stability of the structure will be determined due to reduction of the weight and to test the new interlocking system.

\subsection{Proposed model setup}

The experiment will take place in the Hydraulic Lab of Civil Engineering Department, UPM. The WABCORE model is provided and supplied by National Hydraulics Research Institute (NAHRIM). The WABCORE will be stacked in the pyramid order where the width base is made up of three models and followed by two in the middle, and one model as the top crest. The model will be placed in the middle of the wave flume. For double submerged breakwater setup, two model units will be used. Eight wave probes will be used for this experiment ie four is placed in front of the model while another four is placed behind the breakwater model. The wave probe is functioned to capture the incident wave and transmitted wave heights. Wave absorber is placed at the far end of the wave flume to dampen the transmitted wave and to absorbed dissipation of wave energy so that it can act like a natural beach. The generation of a series of regular and irregular waves with specified heights and periods will be done using a wave generator equipped with the wave flume. Calibration setup prior to model testing will be conducted to ensure the accuracy of the results obtained.

To determine the wave coefficient transmission, 12 waves with different heights $\left(\mathrm{H}_{\mathrm{s}}=0.05 \mathrm{~m}, 0.1 \mathrm{~m}, 0.15 \mathrm{~m}, 0.2 \mathrm{~m}\right.$, $0.25 \mathrm{~m}, 0.30 \mathrm{~m}, 0.35 \mathrm{~m}, 0.40 \mathrm{~m}, 0.45 \mathrm{~m}, 0.50 \mathrm{~m}, 0.55 \mathrm{~m}, 0.60 \mathrm{~m})$ will be generated and the freeboard are varied $(\mathrm{R}=0.05 \mathrm{~m}$, $0.10 \mathrm{~m}, 0.15 \mathrm{~m}, 0.20 \mathrm{~m}, 0.25 \mathrm{~m}, 0.30 \mathrm{~m})$. In addition, three type of wave period is also tested which are $1.3 \mathrm{~s}, 1.5 \mathrm{~s}, 1.7 \mathrm{~s}$ and $2.0 \mathrm{~s}$. Apart from (3:2:1 pyramid order), another set up for the WABCORE unit will be four at the bottom, three in the middle and two as the top crest to vary the crest width. Transmission coefficient can be determined using followed equation.

$$
K_{T}=\frac{H_{t}}{H_{i}}
$$

Wave energy reduction can be calculated by deducting the total wave energy approaching the breakwater with the incident wave energy. To determine the total wave energy, following equation is used.

$$
E=E_{p}+E_{k}=\frac{\rho g H^{2} L}{16}+\frac{\rho g H^{2} L}{16}=\frac{\rho g H^{2} L}{8}
$$

To determine the stability of WABCORE model, two approaches will be adopted (i) scouring and (ii) displacement. Sand will be placed at the seaward slope (facing incident wave) with a specified thickness. Wave breaks at the submerged breakwater is expected to release energy thus create a scour in front of the model structure. The depth of the scour is measured and compared with a threshold value found in the previous study. If he height of the scour exceeds/less than the limit of the threshold value. The model is considered unstable/stable. This method is followed based on [23]. The second method is used by observing the displacement of the breakwater model. Initially, the position of the model will be marked. It is expected that with greater wave heights, the model unit will be move forward by a certain value of displacement. The displacement of the breakwater model will be measured, and percentage of the displacement will be calculated. If the percentage of displacement is greater than $0.5 \mathrm{~L}$, where $\mathrm{L}$ is the unit length, the model is considered unstable. This method is followed based on [45]. The stability test will be run for 3000 and 5000 cycles with the same wave height and freeboard.

\subsection{Expected Results}

From this study several outcomes are expected based on previous studies. Like other submerged breakwater, WABCORE is expected to reduce wave transmission and have similar result as previous WABCORE model as can be seen from study perform by [39] in previous section. This is because the geometry does not change much and only the density is reduced. Based on previous study on submerged breakwater, density is not a factor affecting the wave transmission coefficient. However, it might affect the stability of the structure due to the lighter weight. Since there is no previous study on the stability of the WABCORE, the results cannot be compared so new threshold is set up based on [44] and [45] studies. Although the density is reduced significantly, the interlocking of the structure is improved, and it will increase the stability of the structure. It is expected that the structure is stable. For double submerged breakwater, it is expected that the result will shows the reduction of wave transmission. This can be referred to the study performed by [46]. However, the study was not to compare the single and double submerged breakwater. Hence, there is no indication in result for which one having the lower transmission coefficient. 


\section{References}

1. Hamdani, B. Trihatmodjo and Suharyanyo. Wave Transmission on Submerged Breakwater with Interlocking DBlock Armor. IRJES 4, 16 35-44 (2015)

2. K d'Angremond and F. V. Roode, Breakwaters and Closure Dams. (London, Spon Press, 2004)

3. Department of Irrigation and Drainage Malaysia, Breakwaters, 'The Official Portal for Department of Irrigation and Drainage Malaysia', ( http://www.water.gov.my/activities-mainmenu-184/407) (2010)

4. R. Ranasinghe and I. L. Turner, Shoreline Response to Submerged Structures: A Review. C. Eng. 53, 65-79 (2006)

5. Hung, Chin-Wen \& Chen, Hong-Bin \& Tsai, Ching-Piao. Simulation of Shoreline Change behind a Submerged Permeable Breakwater. Proceedings (7th ICECT 2010), 49-58 (2010)

6. C. Phillips, The Physical Causes of Coastal Erosion (2015)

7. M. Setz and M. Finnegan, Analysis of the Wave Energy Reduction of Rubble Mound Breakwaters (2010)

8. J. Chen, C. Jiang, W. Yang, G. Xiao, Laboratory Study on Protection of Tsunami-Induced Scour by Offshore Breakwaters. Ntrl. Hzrds. 81, 2, 1229-1247 (2015)

9. G. Dhinakaran, V. Sundar, R. Sundaravadivelu, Review of the Research on Emerged and Submerged Semicircular Breakwaters. J. Eng. Martm. Env. 226, 4, 397-409 (2012)

10. U. Tomasicchio and Member ASCE. Submerged Breakwaters for The Defence of The Shoreline at Ostia Field Experiences, Comparison. In Edge B. L. (Ed), Coast. Eng. 1996, 2404-2417 (1996)

11. L. C. Van Rijn, Design of Hard Coastal Structures Against Erosion (2013)

12. D. S. Hur, K. H. Lee, D. S. Choi, Effect of the Slope Gradient of Submerged Breakwaters on Wave Energy Dissipation. Eng. Appl. of Comp. Fld. Mech. 5, 1, 88-98 (2011)

13. A. D. Quinn, Design and Construction of Ports And Marine Structures. (New York, McGraw-Hill, 1972)

14. G. E. Jarlan, A Perforated Vertical Wall Break-water. Dock Harbour Auth. XII, 394-398 (1961)

15. S. Tamrin, Pallu, H. Parung, A. Thaha, Experimental Study of Perforated Concrete Block Breakwater. International. Journal of Engineering. \& Tech. 14, 3, 6-10 (2014)

16. H. Bergmann, H. Oumeraci, Wave Pressure Distribution on Permeable Vertical Walls. In Edge B. L. (Ed), Coast. Eng. 19982042 - 2055 (1998)

17. M. L. Campbell, E. I. Paling, Evaluating Vegetative Transplant Success in Posidonia Australis: A Field Trial with Habitat Enhancement. Mrn. Plln.. Blln 46,7, 828-834 (2003)

18. SSSC. Scour Control (n.d.)

19. K. W. Pilarczyk, R. B. Zeidler, Offshore Breakwaters and Shore Evolution Control (1996)

20. W. T. Bakker, J. Bax, D. Grootenboer, W. H. Tutuarima, Artificial Seaweed: Coastal and Submarine-Pipeline as. La Houille Blanche 8. Page 661-676 (1973)

21. I. Hadibah, Valued-Added Shore Protection Structures for Enhancement of the Marine Ecosystem Services. In Proceeding of the 2003 Technical Seminar on Shoreline Management, Malaysia (2003)

22. R. H. Charlier, C. P. De Meyer, Coastal Erosion: Response and Management. (New York, Springer, 1998)

23. A. S. Kiran, V. Ravichandran, K. M. Sivakholundu, Stability Analysis and Design of Offshore Submerged Breakwater Constructed using Sand Filled Geosynthetic Tubes. Procedia Eng. 116, 310-319 (2015)

24. I. E. Alvarez, R. Rubio, H. Ricalde, Beach Restoration With Geotextile Tubes as Submerged Breakwaters in Yucatan, Mexico. Geotextile and Geomembrane 25, 4-5, 233-241 (2007)

25. Y. I. Oh, E. C. Shin, using Submerged Geotextile Tubes in The Protection of the e. Korean Shore. Coast. Eng. 53, 879-895 (2006)

26. T. R. Barber, G. L Barber, (U.S. Patent No. 5,564,369), U.S. Patent and Trademark Office,Washington, DC U.S. (1996)

27. Reef Beach. Reef Balls as Submerged Breakwaters or for Erosion Control, (www.reefbeach.com (n.d.))

28. The Reef Ball Foundation. Reef Ball Styles, (www.reefball.org (n.d))

29. I. Del Vita, Hydraulic Response of Submerged Breakwaters in Reef Ball Modules (2016)

30. L.E. Harris, Status Report for the Submerged Reef Ball Artificial Reef Submerged Breakwater Beach Stabilization Project for the Grand Cayman Marriott Hotel. www.reefball.org (2003)

31. L. E. Harris, Artificial Reefs for Ecosystem Restoration and Coastal Erosion Protection with Aquaculture and Recreational Amenities. Reef Journal 1,1, 235-246 (2009)

32. L.E. Harris, Designed Reefs Coastal Stabilization and Reef Restoration, (www.artificialreefs.org) (2007) 
33. D. S. Arnouil, Shoreline Response for a Reef Ballтм Submerged Breakwater System offshore of Grand Cayman Island. Degree of Master of Science in Ocean Engineering, Melbourne, Florida (2008)

34. L. E. Harris, Investigations and Recommendations for Solutions to the Beach Erosion Problems in the City of Herzliya, Israel (2007)

35. H. D. Armono, K. R. Hall, Wave Transmission on Submerged Breakwaters Made of Hollow Hemispherical Shape Artificial Reefs. In Canadian Coastal Conference. 313-322. (2003)

36. E. Fatimah, A. K. A. Wahab, H. Ismail, Numerical Modeling Approach of an Artificial Mangrove Root System (ArMS) Submerged Breakwater as Wetland Habitat Protector. In Proceeding of the Seventh International Conference On Coastal snd Port Engineering, (PIANC-COPEDEC VII), 88,1-20 United Arab Emirates (2008).

37. I. Hadibah, F. Eldina, A. K. Abd.Wahab, Wave Energy Dissipation over Pseudo-Mangrove Roots, Innovations \& Technologies in Oceanography for Sustainable Development. Proceedings of the Innovations and Technologies in Ocn. for Stn. Dev. (ITOS 2005) 193-204, 26-29 September, Kuala Lumpur, Malaysia (2005)

38. E. C. Lee, R. S. Douglas, Geotextile Tubes as Submerged Dykes for Shoreline Management in Malaysia. Geotextiles and Geomembranes xxx, $1-8$ (2011)

39. M. D. Safari, A. K. Othman, M. Azuhan, Submerged Breakwater Hydrodynamic Modeling for Wave Dissipation and Coral Restorer Structure (ICBBE '16) 98-101 (2016)

40. J Dattatri, H. Raman, N. J. Shankar, Performance Characteristics of Submerged Breakwaters. In Coastal Engineering 1978. 2153-2171 (1978)

41. S. R. Seabrook, K. R. Hall, Wave Transmission at Submerged Rubblemound Breakwaters. In Coastal Engineering 1998. 2000-2013 (1999)

42. C. Vidal, M. A. Losada, R. Medina, E. P. D. Mansard, \& G. Gomez-Pina, A Universal Analysis for The Stability of Both Low-Crested and Submerged Breakwaters. In Coastal Engineering 1992. 1679-1692. (1993)

43. T. M. Dick, A. Brebner, Solid and Permeable Submerged Breakwaters. In Coastal Engineering 1968. 1141-1158. (1969)

44. M. Mohd Fauzi, S. Y. Ang, H. Saiful Bahri, S. Mohd Kamarul Huda, Colonization of Marine Epibiota around WABCORE Artificial Reef at Panuba Bay, Tioman Island, Malaysia. APCBEE Procedia 5, 416-422 (2013).

45. M. Muttray, E. ten Oever, B. Reedijk, Stability of Low Crested and Submerged Break waters with Single Layer Armouring. J. of Ship. and Ocn. Eng. 2, 140-152 (2012)

46. Y. Cao, C. Jiang, Y. Bai, Wave Attenuation Properties of Double Trapezoidal Submerged Breakwaters on FlatBed. Transactions of Tianjin University 18, 6, $40-410$. (2012) 